\title{
, CORRESPONDENCE
}

Raw or pasteurised human milk?

A Lucas, MRCP, and others......... 781

Scope for family doctors

$M$ E $M$ Herford, $M D$.

Legionnaires' disease in London

P F Mitchell-Heggs, MRCP, and others... . 782

Nutrition education

A S Truswell, FRCP; J S Bradshaw, MB.... 782

Subarachnoid haemorrhage in patients over 59

W J Atkinson, FRCS; P Horrocks, MRCP, and J Knox, MRCPED; J C Taylor, FRCS . . . . . . 783 Testing monocyte function

P C J Leijh, BSC, and others.

Induction and neonatal jaundice in infants of diabetics

N G Soler, MD.

College of Anaesthetists

M P Coplans, FFARCS

Papilloedema

J A E Primrose, FRCSED.

Eruption during treatment with

oxprenolol

G M Levene, MRCP, and R W Gange, MRCP 784

Psychological evaluation in cases of self-poisoning

A H Ghodse, MD; R Gardner, MRCPSYCH . . 784

Drug treatment of chronic stable angina pectoris

R H Rousell, MSC, $\mathrm{MB}$, and Geraldine $\mathrm{K}$

Dodd, BSC................... 785

Ectopic pregnancy rates in IUD users R Aznar, MD, and others............ How not to apply for an appointment

I Gregg, FRCGP. .

"Baby and Child",

D P Addy, MRCP............. 786

Stiff-neck syndrome

Mary Ducrow, FFARCs............ 786

Plasma urate changes in pre-eclampsia

W Dunlop, MRCoG, and J M Davison, MRCOG 786

Osteoporosis and osteomalacia

H C Anton, FRCR............. 786

Antacid and sodium content of Gaviscon

A W Harcus, $\mathrm{MB} . \ldots \ldots \ldots \ldots \ldots \ldots 78$

Hot foot syndrome

I C M Paterson, FRCR . . . . . . . . 787

Cost of outpatient chemotherapy

D O R S Thomson................. 787

Snap-happy parents

$\mathrm{H}$ A Goodwin, MB, DCH.

784 Help for parents after stillbirth

Deborah Howell, MSC.

Drawbacks of monocomponent insulins

M E Benaim, MRCP............ 788

Mumps and its complications in

Stockholm

B Bjorvatn, MD, and B Sköldenberg, MD. 788

GP obstetrics

M J V Bull, MrCGP... . . . . . . . . . . . . 788

Alcohol and cirrhosis

G C Myddelton, MB. .
Traumatic tenosynovitis of the wrist H O Paton, мв.............. 789 Factors affecting length of hospital stay

R Hole, FRCS.................... 789

Inactivation of agent of Creutzfeldt-Jakob disease

A M M Wilson, frcpath. . . . . . . . 789

Aids to drug compliance

B C Das, MB, and A Williams, MPs..... 789

Otosclerosis

Flora Jacobs.................. 790

Bromocriptine-induced mania?

Nancy M Brook, DPH, and I B Cookson,

MRCPSYCH. . . . . . . . . . . . . . . . 790

Typhoid and its serology

A F M S Rahman, MRCPATh, and $M$ E

Cowan, msc.................. 790

Hazard of chemical sympathectomy

A P Rubin, FFARCS, and B R Master, FFARCS 790

"The Way Forward"

J A Girling, FRCS. .

New consultant contract

$\mathrm{C} \mathrm{H}$ Thomas, FFARCS.

Short-term medical certificates

C J Nettle, мв................ 791

Subconsultant grade

J S M Zorab, FFARCS ........... 791

Robbing Peter to pay Paul?

T McFarlane, MrCog.............. 791

Redundant doctors

R T Parry.................. 79 